\title{
Health Care and Milking Management Practices followed by Buffalo Owners in Katol Tahsil of Nagpur District, India
}

\author{
Devshree Panchbhai* and S. G. Gubbawar \\ Department of Animal Husbandry and Dairy Science, Agriculture College, Nagpur, India \\ *Corresponding author
}

\section{A B S T R A C T}

Keywords

Scientific feeding practices, health and sanitation, milking practices

Article Info

Accepted:

25 March 2021

Available Online:

10 April 2021
The present investigation was undertaken to know the various management practices adopted by buffalo owners. A sample of 200 farmers was classified into three categorized viz., small, medium and large based on the land holdings, in Katol tahsil. About 40.00 per cent of farmers in the age group of 41-50 years were engaged in buffalo rearing while only 6.50 per cent of young farmers (21-30 year) had shown their interest in buffalo rearing. Majority of the farmers 53.00 percentage observed heat by mucus discharge while 21.50 per cent farmers through slightly off feed. About 72.00 per cent farmers mated their animal within 12 hours and 27.50 per cent within 12-18 hours. About 83.00 per cent farmers adopt natural method of insemination and artificial insemination by 17.00 per cent farmers. Buffalo owners were well aware regarding health care practices viz., eradication of ectoparasites, regular vaccination and deworming.

\section{Introduction}

Buffalo is major integrale component of the Indian dairy farming. It is important source of milk, meat and draft power in India. In India buffalo is very popular and commonly reared in large dairy farms and also for domestic milk production.

The role of dairy farming in the Indian rural economy is very outstanding. The significance is heightened by its massive contribution of livelihood of India's rural population. Over 73 per cent of India's households have their own livestock. Grazing, feeding and milking of cows and buffaloes is one of the largest source of productive employment in rural India (Ahirwar et al., 2010). Buffalo is the 'Black Gold' of small and marginal farmers as well as landless labours and important in conserving the rural environment.

Buffalo is the main dairy animal of India which provides economic stability to farmers 
through sale of milk and sale of animals due to uncertainties associated with crop farming in dry land /rainfed area, which constitutes 70 per cent of arable land of India. Buffalo population nearly 94 million contributes about 56 per cent of the total milk production as compared to that of nearly 218 million cattle population of the country (Sastry 2003). Milk is leading agricultural produce contributing about 4 per cent to the total GDP of India (Banerjee 2005). In addition buffaloes are important sources of draft power, meat, organic manure, fuel, skin and bones and thus, involvement in buffalo production is seen as 75 a potential means of raising the living standard for small and marginal farmers and landless agricultural workers (Kalyankar 2008).

Keeping these in view, an attempt was made to study on the management practices adopted by buffalo owners in Katol tehsil of Nagpur district (M.S.).

\section{Materials and Methods}

The study was carried out around Katol city during the year 2014-15. Ten villages viz. Wandali, Dongargoan, Isapur, Sonoli, DhartiMurti, Kacharisavanga, Ridhora, Kukadipanjara, Paradsinga, Mendaki were randomly selected. The information on dairy farming practices was obtained from the Buffalo owners through personal interaction with the help of questionnaire from selected villages for the study. The list of 200 Buffalo owners was prepared form village with help of gramsevak and livestock development officer of Panchayat Samiti.

The data with regards to various aspects of study such as land holding, cropping pattern, crossbred cattle owners, availability of feed and fodders, grazing facilities, milk yield, routine management practices, availability of shed, number of milch animals and availability of veterinary facility etc. were collected. The data were tabulated and analyzed by simple tabular techniques to ascertain the objectives under study.

\section{Results and Discussion}

\section{Health Care Management}

It was revealed from that, buffaloes suffered from diarrhea aliment (36.66 per cent) followed by foot and mouth (03.33 per cent), black quarter (10.22 per cent) and hemorrhagic septicemia (09.55 per cent). Buffaloes also suffered from fever (14.66 per cent) and indigestion (13.11 per cent), whereas 18.22 per cent buffaloes did not suffered from any disease. Gupta and Arneja (1981) reported that all the farmers vaccinated their animals to prevent from diseases like Hemorrhagic septicemia, Black quarter and Foot and mouth disease. The results confirm the observations reported by Jamal et al., (2012) and Ahirwar et al., (2010). It was further observed that, about 71.00 per cent farmers followed eradication of ecto-parasites and 74.44 per cent farmer followed regular vaccination.

Whereas 71.00, 69.50 and 09.50 per cent farmers followed eradication of ecto-parasites, regular vaccination against diseases and regular deworming in 74.44, 71.11,11.55 and per cent of buffaloes respectively. Jamal et al., (2012) reported that majority (95.2 per cent) of respondents was aware about dipping against ectoparasites and 43.2 per cent of the respondents were adopting it. Different vaccines were being used. Rathore and Khanchwaha (2009) observed that about 63.50 per cent farmers preferred and consulted first with the quacks than veterinary doctors for treatment of sick animals. Only 18.75 and 22.25 per cent of the respondents followed vaccination and deworming practices.

The result confirm the observation reported by 
Dhiman et al., (1990), Belli and Manjula (1997).

\section{Milking management}

It was observed from that, (52.50 per cent) of farmers undertook washing of the buffaloes ones a day while, (37.50 per cent) farmers adopted washing twice a day. About $(09.50$ per cent) buffalo farmers did not follow regular washing of buffaloes. It was also observed that ( 74.50 per cent) farmers adopted the wallowing practice, whereas $(25.50$ per cent) farmers not fallow this practice. Aulakh et al., (2012) observed that 23.33 per cent buffalo wallowing in the pond.

It was further observed that majority of farmers (82.50 per cent) followed regular shaving practices for (84.44) buffaloes. The majority of the farmers (97.50 per cent) adopted washing of udder before starting of milking of (97.78) buffaloes. Kishore et al., (2013) observed that about 49.16 per cent farmers washed their animals by splashing water manually.

Table.1 Distribution of dairy farmers according to attitude towards knowledge about common diseases of buffaloes

\begin{tabular}{|l|l|c|c|}
\hline $\begin{array}{l}\text { Sr. } \\
\text { No. }\end{array}$ & Particulars & Number of farmers & Per cent \\
\hline $\mathbf{1}$ & Known about common diseases & 175 & 87.50 \\
\hline $\mathbf{2}$ & Unknown about common diseases & 25 & 12.50 \\
\hline & Total & 200 & 100.00 \\
\hline
\end{tabular}

(Figures in parenthesis indicated percentage to the total)

Table.2 Distribution of dairy farmers according to attitude towards out-break of common diseases in buffaloes

\begin{tabular}{|l|l|c|c|}
\hline Sr. No. & Particulars & $\begin{array}{c}\text { Number of } \\
\text { farmers } \\
(\mathbf{N = 2 0 0})\end{array}$ & $\begin{array}{c}\text { Number of } \\
\text { buffaloes } \\
(\mathbf{N = 4 5 0})\end{array}$ \\
\hline $\mathbf{1}$ & Diarrhea & 50 & 139 \\
& & $(25.00)$ & $(36.66)$ \\
\hline $\mathbf{2}$ & Fever & $(17.50)$ & 66 \\
& & 32 & $(14.66)$ \\
\hline $\mathbf{3}$ & Indigestion & $(16.00)$ & $(13.11)$ \\
\hline $\mathbf{4}$ & Black quarter & 20 & 46 \\
& Hemorrhagic septicemia & $(10.00)$ & $(10.22)$ \\
\hline $\mathbf{5}$ & & $(07.50)$ & $(09.55)$ \\
\hline $\mathbf{6}$ & Foot and mouth disease & 08 & 15 \\
\hline $\mathbf{7}$ & Not suffered by any disease & $(04.00)$ & $(03.33)$ \\
\hline & & $(20.00)$ & 82 \\
\hline
\end{tabular}


Table.3 Distribution of dairy farmers according to veterinary facilities and disease control practices

\begin{tabular}{|c|c|c|c|}
\hline $\begin{array}{l}\text { Sr. } \\
\text { No. }\end{array}$ & Particulars & Numbers of farmers & Number of buffaloes \\
\hline I & \multicolumn{3}{|c|}{ Availability of veterinary facilities } \\
\hline a. & Yes & $\begin{array}{c}165 \\
(82.50)\end{array}$ & $\begin{array}{c}355 \\
(78.89)\end{array}$ \\
\hline \multirow[t]{2}{*}{ b. } & No & $\begin{array}{c}35 \\
(17.50)\end{array}$ & $\begin{array}{c}95 \\
(21.11)\end{array}$ \\
\hline & Total & $\begin{array}{c}200 \\
(100.00)\end{array}$ & $\begin{array}{c}450 \\
(100.00)\end{array}$ \\
\hline II & \multicolumn{3}{|c|}{ Eradication of ecto-parasite } \\
\hline a. & Done & $\begin{array}{c}142 \\
(71.00)\end{array}$ & $\begin{array}{c}335 \\
(74.44)\end{array}$ \\
\hline \multirow[t]{2}{*}{ b. } & Not-done & $\begin{array}{c}58 \\
(29.00)\end{array}$ & $\begin{array}{c}115 \\
(25.55)\end{array}$ \\
\hline & Total & $\begin{array}{c}200 \\
(100.00)\end{array}$ & $\begin{array}{c}450 \\
(100.00)\end{array}$ \\
\hline III & \multicolumn{3}{|c|}{ Regular vaccination against diseases } \\
\hline a. & Done & $\begin{array}{c}139 \\
(69.50)\end{array}$ & $\begin{array}{c}320 \\
(71.11)\end{array}$ \\
\hline \multirow[t]{2}{*}{ b. } & Not-done & $\begin{array}{c}61 \\
(30.50)\end{array}$ & $\begin{array}{c}130 \\
(28.88)\end{array}$ \\
\hline & Total & $\begin{array}{c}200 \\
(100.00)\end{array}$ & $\begin{array}{c}450 \\
(100.00)\end{array}$ \\
\hline IV & \multicolumn{3}{|c|}{ Regular deworming of buffaloes } \\
\hline a. & Done & $\begin{array}{c}11 \\
(09.50)\end{array}$ & $\begin{array}{c}52 \\
(11.55)\end{array}$ \\
\hline b. & Not-done & $\begin{array}{c}181 \\
(90.50)\end{array}$ & $\begin{array}{c}398 \\
(88.44)\end{array}$ \\
\hline & Total & $\begin{array}{c}200 \\
(100.00)\end{array}$ & $\begin{array}{c}450 \\
(100.00)\end{array}$ \\
\hline
\end{tabular}


Table.4 Distribution of dairy farmers according to attitude towards milking management

\begin{tabular}{|c|c|c|c|}
\hline Sr. No. & Particulars & Number of farmers & Number of buffaloes \\
\hline I & \multicolumn{3}{|c|}{ Frequency of washing /wallowing of buffalo } \\
\hline a. & Once a day & $\begin{array}{c}105 \\
(52.50)\end{array}$ & $\begin{array}{c}221 \\
(49.11)\end{array}$ \\
\hline b. & Twice a day & $\begin{array}{c}75 \\
(37.50)\end{array}$ & $\begin{array}{c}178 \\
(39.56)\end{array}$ \\
\hline \multirow[t]{2}{*}{ c. } & Not-done & $\begin{array}{c}19 \\
(9.50)\end{array}$ & $\begin{array}{c}51 \\
(11.33)\end{array}$ \\
\hline & Total & $\begin{array}{c}200 \\
(100.00)\end{array}$ & $\begin{array}{c}450 \\
(100.00)\end{array}$ \\
\hline II & \multicolumn{3}{|c|}{ Wallowing in pond/nallas } \\
\hline a. & Done & $\begin{array}{c}149 \\
(74.50)\end{array}$ & $\begin{array}{c}352 \\
(78.22)\end{array}$ \\
\hline \multirow[t]{2}{*}{ b. } & Not-done & $\begin{array}{c}51 \\
(25.50)\end{array}$ & $\begin{array}{c}98 \\
(21.78)\end{array}$ \\
\hline & Total & $\begin{array}{c}200 \\
(100.00)\end{array}$ & $\begin{array}{c}450 \\
(100.00)\end{array}$ \\
\hline III & \multicolumn{3}{|c|}{ Regular shaving of buffalo } \\
\hline a. & Done & $\begin{array}{c}165 \\
(82.50)\end{array}$ & $\begin{array}{c}380 \\
(84.44)\end{array}$ \\
\hline \multirow[t]{2}{*}{ b. } & Not-done & $\begin{array}{c}35 \\
(17.50)\end{array}$ & $\begin{array}{c}70 \\
(16.56)\end{array}$ \\
\hline & Total & $(100.00)$ & $(100.00)$ \\
\hline III & \multicolumn{3}{|c|}{ Washing of udder and teats before milking } \\
\hline a. & Done & $\begin{array}{c}195 \\
(97.50)\end{array}$ & $\begin{array}{c}440 \\
(97.78)\end{array}$ \\
\hline \multirow[t]{2}{*}{ b. } & Not-done & $\begin{array}{c}5 \\
(02.50)\end{array}$ & $\begin{array}{c}10 \\
(2.22)\end{array}$ \\
\hline & Total & $\begin{array}{c}200 \\
(100.00)\end{array}$ & $\begin{array}{c}450 \\
(100.00)\end{array}$ \\
\hline IV & \multicolumn{3}{|l|}{ Method of milking } \\
\hline a. & Full hand milking & $\begin{array}{c}78 \\
(39.00)\end{array}$ & $\begin{array}{c}176 \\
(39.12)\end{array}$ \\
\hline b. & Knuckling method & $\begin{array}{c}105 \\
(52.50)\end{array}$ & $\begin{array}{c}240 \\
(53.33)\end{array}$ \\
\hline \multirow[t]{2}{*}{ c. } & Stripping method & $\begin{array}{c}17 \\
(8.50)\end{array}$ & $\begin{array}{c}34 \\
(7.55)\end{array}$ \\
\hline & Total & $\begin{array}{c}200 \\
(100.00)\end{array}$ & $\begin{array}{c}450 \\
(100.00)\end{array}$ \\
\hline $\mathbf{V}$ & \multicolumn{3}{|c|}{ Types of milking pails } \\
\hline a. & Open mouth bucket & $\begin{array}{c}187 \\
(93.50)\end{array}$ & $\begin{array}{c}412 \\
(91.55)\end{array}$ \\
\hline
\end{tabular}




\begin{tabular}{|l|l|c|c|}
\hline b. & Scientific milking pail & $\begin{array}{c}13 \\
(06.50)\end{array}$ & $(08.44)$ \\
\hline & Total & 200 & 450 \\
& & $(100.00)$ & $(100.00)$ \\
\hline VI & Change in milker & 45 & 58 \\
\hline a. & Yes & $(22.50)$ & $(12.88)$ \\
\hline b. & No & 155 & 392 \\
& & $(77.55)$ & $(87.11)$ \\
\hline & Total & 200 & 450 \\
& & 100.00 & $(100.00)$ \\
\hline
\end{tabular}

Washing of the animals and of their udders before milking were practiced by 15.68 per cent and 98.40 per cent farmers. The same trend was also reported by Shitole et al., (2009) and Bainwad et al., (2007). As regards the adoption of method of milking, it was observed that buffalo farmers used knuckling method of milking followed by full hand and stripping method and proportion was 52.50, 39.00 and 08.50 per cent of buffaloes, respectively. Majority of buffalo farmers used a knuckling method of milking, than the recommended method full hand milking indicating a burning need of conducting an orientation training to educate the farmers regarding safe and hygienic method of milking for clean milk production. Malik and Nagpaul (1999) observed that 63.89 per cent of the farmers were adopting the knuckling method of milking. Same trend was also reported by Rathore and Kanchwaha (2009).

It was observed that from Table no.11 that type (93.50 per cent)farmers used open mouth bucket (91.55 per cent) buffaloes and (06.50 per cent) farmers used scientific milking pails(08.44) buffaloes Patbandna (2014) observed that (97.02 per cent) farmers used open mouth bucket at the time of milking and (02.92 percent) farmers used scientific milking pails.

It was further observed that change in milker at the time of milking. (22.50 per cent) farmers changes milker (12.88 per cent) of buffalos at the time of milking and (77.50 per cent) farmers not change Milker (87.11 per cent) buffalos at the time of milking. Patbandha (2014) observed that $(80.00$ per cent) farmers change milker at the time of milking and (20.00 per cent) famers do not change the milker at the time of milking.

The majority of the buffalo owners were well aware about health care and milking management practices. There was a worth notable gap in feeding of green fodder and concentrates in buffaloes.

\section{References}

Ahirwar, R. R., A. Singh and M. I. Qureshi, 2010. Study of management practices in water buffalo (Bubalusbubalis) in India. Buffalo Bulletin 29(1):43-51.

Aulakh, G. S. and R. Singh, 2012. Adoption of recommonded management practices by the buffalo owners. Indian J. of Dairy Sci. 65(5):431-434.Belli, R. B. and N. Manjula. 1997. Adoption of dairy management practices by tribal Gavalis. Maharashtra Journal Extension Education XVI : 137-142.

Dhaiman P. C., Narendra Singh and B. L. Yadav. 1990. A study of dairy cattle and buffalo management practices in adopted and non - adopted villages of Hissar district. Indian J. Ani. Prod. 
Mgmt. 6(2): 90-94.

Kalyankar S. D., A. A. Chavan, C. D. Khedkar and S. P. Kalyankar, 2008. Studies on management practices of buffaloes in different agro- climatic zones of Maharastra. Indian J. of Anim. Res. 42(3):157-163.

Malik, D. S., and P. K. Nagpual, 1999. Studies on milking and calf rearing management practices of Murrah buffalo in home tract of Haryana. Indian J. of Anim. Prod. Mgmt. 15(2):51-54.

Patbandha T. K., S. Harandi., R. Pathak., A. L. Ahlawat 2014. A Study on milking management practices adopted by dairy farmer for clean milk production in south saurashtra Agroclimatic region

of

Gujarat.J.Interacad.18(4):589-596.

Rathore R. S. and R. N. Kachwaha, 2009.

Studies on existing management practices followed by buffalo owners in Jhunjhuna district of Rajasthan. Indian J. of Anim. Prod. and Mgmt. 25(1/2):8-12.

Sastry, N. S. R., 2003. Studies on management practices of buffaloes in different agroclimatic zones of Maharashtra. Proc. $4^{\text {th }}$ Asian Buffalo Congress 25-28th Feb. New Delhi. 1: 169-171.

Shitole, D. P., B. R. Deshmukh, U. B. Kashid and R. R. Chavan, 2009. Studied on Management Practices of Buffaloes in Parbhani district. Indian J. Anim.l Res. 43(4):251-254.

\section{How to cite this article:}

Devshree Panchbhai and Gubbawar, S. G. 2021. Health Care and Milking Management Practices followed by Buffalo Owners in Katol Tahsil of Nagpur District, India. Int.J.Curr.Microbiol.App.Sci. 10(04): 869-875. doi: https://doi.org/10.20546/ijcmas.2021.1004.091 